DIMENSI, VOL. 8, NO. 2 : 307-316

JULI 2019

ISSN: 2085-9996

\title{
Efek Harga, Promosi dan Kualitas Layanan terhadap Loyalitas Pelanggan melalui Kepuasan Pelanggan
}

\section{Effect Pricing, Promotion and Service Quality to Customer Loyalty through Customer Satisfaction}

\author{
${ }^{1}$ Herni Widiyah Nasrul, Zulkifli ${ }^{2}$

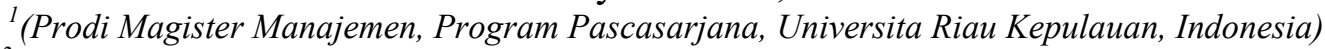 \\ 2 (Prodi Magister Manajemen, Program Pascasarjana, Universitas Riau Kepulauan, Indonesia) \\ herni@yahoo.com,2zulkifli@gmail.com
}

\begin{abstract}
Abstrak
Tujuan penelitian menguji kepuasan konsumen dalam menerima layanan berkualitas dan kepuasan pelanggan yang dirasakan ketika membeli Burger King makanan cepat saji di kota Batam. Kualitas layanan dan kepuasan pelanggan dalam mempengaruhi minat pembelian berulang konsumen diuji pada konsumen setelah pembelian makanan cepat saji Burger King di kota Batam. Data dikumpulkan dengan menyebarkan kuesioner kepada 93 responden yang mempertanyakan metode penyebaran kuesioner. Penelitian ini menunjukkan bahwa hasil model struktural I, penjualan langsung dan kualitas layanan memiliki hubungan yang signifikan dengan kepuasan pelanggan. Struktural II langsung pada harga, promosi dan kepuasan pelanggan berpengaruh signifikan terhadap loyalitas pelanggan dan secara tidak langsung melalui Kualitas Layanan Kepuasan Pelanggan berpengaruh signifikan terhadap loyalitas pelanggan. Nilai $R$ Square $=0,568$ menunjukkan bahwa Harga, Promosi, Kualitas Layanan dan Kepuasan Pelanggan terhadap Loyalitas Pelanggan sebesar 56,8\% sementara sisanya 43,2\% dikontribusikan oleh faktor-faktor lain di luar penelitian. Kesimpulan dari penelitian ini, baik secara langsung maupun tidak langsung melalui variabel kualitas pelayanan kepuasan pelanggan lebih berpengaruh signifikan terhadap loyalitas pelanggan dari variabel Harga dan Promosi. Implikasi dari penelitian ini adalah perlunya peningkatan promosi dan kebijakan harga.
\end{abstract}

Kata kunci: Harga, Promosi, Kualitas Layanan, Kepuasan Pelanggan, Loyalitas Pelanggan

\begin{abstract}
The research objective will try to test consumer satisfaction in receiving quality service and customer satisfaction that is felt when buying fast food Burger King in the city of Batam. Quality of service and customer satisfaction in influencing consumer repeat purchase interest is tested on consumers after the purchase of Burger King fast food in the city of Batam. Data were collected by distributing questionnaires to 93 respondents question the method of distributing the questionnaire. This study shows that the results of the structural model I, direct sale and service quality has a significant relationship with customer satisfaction. Structural II directly on price, promotion and customer satisfaction significantly influence customer loyalty and indirectly through Customer Satisfaction Service Quality significant effect on customer loyalty. The value of $R$ Square $=0.568$ indicates that Price, Promotion, $Q$ uality of Service and Customer Satisfaction to Customer Loyalty of $56.8 \%$ while the remaining $43.2 \%$ was contributed by other factors outside of the study. The conclusion from this research, either directly or indirectly through customer satisfaction service quality variables more significant effect on customer loyalty of the variable Price and Promotion. The implication of this research is need for increased promotion and price policy.
\end{abstract}

Keywords: Pricing, Promotion, Service Quality, Customer Satisfaction, Customer Loyalty 


\section{PENDAHULUAN}

Pada masa periode sekarang ini keadaan persaingan semakin menjamur dan semakin ketat, perkembangan persaingan bisnis di Indonesia merupakan salah satu fenomena yang sangat menarik untuk kita amati. Setiap perusahaan harus dapat menciptakan suatu strategi yang tepat dalam mengikuti persaingan. Strategi tidak hanya dilakukan dari harga ataupun promosi melainkan kualitas pelayanan yang dapat memuaskan pelanggan saat jasa itu dilakukan. Produk yang baik tetapi tidak diimbangi dengan pelayanan yang baik rasa akan percuma karena konsumen sekarang ini tidak hanya sekedar membeli produk, tetapi juga segala aspek jasa atau pelayanan pada produk tersebut mulai dari tahap pra pembelian hingga tahap purna beli (Sofyan, 2013). Oleh karena itu hal tersebut mendorong persaingan saat ini tidak hanya memberikan produk yang terbaik akan tetapi juga pelayanan pra pembelian ataupun purna pembelian, karena perilaku konsumen dalam mengambil keputusan untuk membeli dan memilih kembali. Disini peneliti akan mencoba menguji kepuasan yang dirasakan konsumen King Burger di Kota Batam.

Pada dasarnya perusahaan mempunyai misi atau tujuan akhir dalam mencapai tingkat keuntungan yang sebesar-besarnya baik itu laba maupun kepuasan pelanggan yang ingin dicapai oleh perusahaan. Konsep penjualan ialah hanya menjual produk yang diinginkan produsen, sedangkan konsep pemasaran lebih mementingkan pada konsep kepuasan. Sejumlah perusahaan menyadari bahwa adanya tingkat persaingan yang semakin ketat, maka dari itu perusahaan perlu meningkatkan efesiensi, promosi dan kualitas pelayanan untuk mencapai kepuasan pelanggan, intinya bahwa kepuasan dari pelanggan penting untuk meningkatkan keuntungan yang maksimal. Hubungan antara perilaku penjual dan pembeli dapat mendorong kepasar sendiri karena saling membutuhkan, saling ketergantungan dan masih banyak aspek suatu pertemuan yang perlu dikembangkan secara lebih mendalam. Perusahaan tidak dapat menilai kualitas pelayanan secara fisik sehingga perusahaan harus dapat membuat pelanggan merasa puas dengan pelayanan dan mempunyai suatu persepsi yang positif terhadap hasil produk yang diterima, dengan begitu pelanggan akan terbentuk keinginan mencoba membeli kembali untuk menjadi pelanggan yang setia. 
Kepuasan dan persepsi tersebut yang akan menjadi suatu pedoman bagi pelanggan dalam memilih suatu jasa pelayanan suatu produk. Hal ini mendorong peneliti melakukan pengujian kepuasan konsumen yang mempengaruhi kesetiaan pelanggan dalam menggunakan jasa pelayanan suatu produk dengan pedoman dasar atas persepsi kualitas layanan dan produk yang diterima oleh pelanggan. Dalam pengujian kali ini akan mencoba memprediksikan seberapa besarnya pengaruh dari efek harga, promosi dan kualitas pelayanan terhadap kesetiaan pelanggan, melalui kepuasan konsumen pada King Burger di kota Batam.

\section{Harga}

Harga merupakan salah satu faktor yang berpengaruh terhadap kepuasan konsumen, karena harga yang telah ditetapkan oleh perusahaan menjadi tolak ukur untuk mencapai kepuasan, hal ini dikarenakan harga merupakan salah satu bahan pertimbangan bagi konsumen untuk membeli suatu produk. Harga yang terjangkau diimbangi dengan kualitas yang baik akan memberikan kepuasan konsumen.

Dengan demikian dapat disimpulkan bahwa pada tingkat harga tertentu, jika manfaat yang dirasakan meningkat, maka nilainya akan meningkat pula. Dengan kata lain semakin terjangkaunya harga suatu produk maka akan semakin besar kepuasan yang dirasakan konsumen. Hal ini dipertegas dengan hasil dari penelitian yang di lakukan oleh Harjanto dan Ardhana (2010) yang menunjukan bahwa harga berpengaruh positif terhadap kepuasan pelanggan. Dalam penelitian yang dilakukan oleh Farisa (2008:36) mengenai analisis faktorfaktor yang mempengaruhi kepuasan pelanggan GSM Indosat di kota Semarang, hasil penelitiannya menyatakan bahwa harga berpengaruh positif terhadap kepuasan konsumen.

\section{Promosi}

Promosi banyak diterapkan untuk menjalin relasi antara perusahaan dan pelanggan. Biasanya program ini memberikan semacam penghargaan (rewards) khusus, seperti bonus, diskon, voucher, dan hadiah yang dikaitkan dengan frekuensi pembelian atau pemakaian produk atau jasa perusahaan kepada pelanggan rutin (heavy users) agar tetap loyal pada produk dari perusahaan bersangkutan. Melalui kerjasama seperti itu diharapkan kemampuan menciptakan dan mempertahankan kepuasan pelanggan akan semakin besar. 
Adanya promosi maka akan sangat membantu produk yang ditawarkan, sehingga adanya promosi tersebut diharapkan masyarakat cepat mengetahui produk yang dijual dan melakukan pembelian. Kotler (2009) menjelaskan pomosi sebagai usaha untuk memberikan informasi pada pasar tentang produk atau jasa yang dijual, tempat dan saatnya. Promosi memiliki peranan penting untuk mengkomunikasikan keberadaan dan nilai produk kepada calon pelanggan.

\section{Kualitas Pelayanan}

Kualitas pelayanan adalah tindakan atau kinerja yang menciptakan manfaat bagi konsumen dengan mewujudkan perubahan yang diinginkan dalam diri atau atas nama penerima (Lovelock dan Wright, 2007). Definisi lain pelayanan adalah setiap tindakan atau kegiatan yang dapat ditawarkan oleh satu pihak kepada pihak lain, yang pada dasarnya tidak berwujud dan tidak mengakibatkan kepemilikan apapun (Laksana, 2008).

Menurut Kotler dan Amstrong (2008), pelayanan adalah semua kegiatan atau manfaat yang dapat ditawarkan suatu pihak kepada pihak lain, yang pada dasarnya tak berwujud dan tidak menghasilkan kepemilikan sesuatu. Juga menurut Kotler dan Keller (2009), pelayanan adalah semua tindakan atau kinerja yang dapat ditawarkan satu pihak kepada pihak lain yang pada intinya tidak berwujud dan tidak menghasilkan kepemilikan apapun. Karena variabel kualitas pelayan tersebut diukur dengan persepsi, sehingga berpengaruh positif

\section{Kepuasan Konsumen}

Setiap para pelaku usaha berharap bahwa pencapaian upayanya tidak berhenti pada satu titik dimana para pelanggannya mengalami kepuasan, tetapi selalu berharap bahwa pelanggannya akan menjadi loyal terhadap produk atau jasa yang dikonsumsinya. Karena menurut Olorunniwo, et.Al, 2006, Michel, et.al, 2000; Kandampully, et.al, 2000; Kartajaya, 2007 dalam Astawa, 2008, pelanggan yang terpuaskan cenderung untuk loyal terhadap penyedia barang atau jasa.

Menurut Schanaars (dalam Tjiptono 2007) pada dasarnya tujuan dari bisnis adalah menciptakan para pelanggan yang merasa puas. Terciptanya kepuasan pelanggan dapat memberikan beberapa manfaat, diantaranya beberapa hubungan antara perusahaan dengan 
pelanggannya menjadi harmonis, memberikan dasar yang baik bagi pembelian ulang dan terciptanya loyalitas pelanggan, dan membentuk suatu rekomendasi dari mulut ke mulut.

\section{Kesetiaan Pelanggan}

Pelanggan yang setia adalah mereka yang sangat puas dengan produk tertentu sehingga mempunyai antusiasme untuk memperkenalkannya kepada siapapun yang mereka kenal. Selanjutnya, pada tahap berikutnya, pelanggan yang loyal tersebut akan memperluas "kesetiaan" mereka kepada produk-produk lain buatan produsen yang sama. Pada akhirnya mereka adalah konsumen yang setia kepada produsen tertentu untuk selamanya Nuraini (2009).

Loyalitas dalam minat pembelian ulang konsumen merupakan keputusan secara individu untuk menggunakan atau mengkonsumsi kembali suatu produk atau jasa untuk situasi yang sama pada waktu yang akan datang pembelian ulang dilakukan konsumen jika konsumen merasakan kepuasan atas produk atau jasa yang dibeli sebelumnya Ferrinadewi (2005), menyatakan bahwa kepuasan pelanggan telah banyak menjadi topik penelitian, hal ini disebabkan karena adanya keterkaitan antara kepuasan pelanggan dengan loyalitas pelanggan. Loyalitas pelanggan menjadi tujuan akhir perusahaan.

\section{Efek Harga terhadap Kepuasan Konsumen}

Harga murah merupakan sumber kepuasan yang penting karena mereka akan mendapatkan value for money yang tinggi. Komponen harga merupakan hal penting dan sangat signifikan pengaruhnya terhadap kepuasan pelanggan yang akan berdampak positif terhadap kesetiaan pelanggan. Hal utama yang perlu disadari oleh seorang pengusaha adalah bagaimana menciptakan sebuah produk yang bermanfaat dan sesuai dengan harapan konsumen.

Dengan demikian dapat disimpulkan bahwa pada tingkat harga tertentu, jika manfaat yang dirasakan meningkat, maka nilainya akan meningkat pula. Dengan kata lain semakin terjangkaunya harga suatu produk maka akan semakin besar kepuasan yang dirasakan konsumen. Hal ini dipertegas dengan hasil dari penelitian yang dilakukan oleh Harjanto dan Ardhana (2010) yang menunjukan bahwa harga berpengaruh positif terhadap kepuasan pelanggan. Dalam penelitian yang dilakukan oleh Farisa (2008:36) mengenai analisis faktor- 
faktor yang mempengaruhi kepuasan pelanggan GSM Indosat di kota Semarang, hasil penelitiannya menyatakan bahwa harga berpengaruh positif terhadap kepuasan konsumen.

\section{Efek Promosi terhadap Kepuasan Konsumen}

Khan et., al (2012) menjelaskan promosi sebagai bentuk yang berbeda dari kegiatan untuk menarik dan mendapatkan perhatian pelanggan untuk membeli produk atau jasa melalui personal selling, hubungan masyarakat, promosi penjualan dan iklan. Promosi produk atau jasa membantu dalam cara terbaik untuk membangun hubungan dengan pelanggan, karena semua orang mencari kesepakatan terbaik yang cocok untuk mereka. Hasil penelitian Khan, et al., (2012) memberikan hasil bahwa terdapat pengaruh positif antara promosi terhadap kepuasan konsumen.

\section{Efek Kualitas Pelayanan terhadap Kepuasan Konsumen}

Menurut Parasuraman, et al. (2008), kualitas pelayanan dapat didefinisikan sebagai seberapa jauh perbedaan antara kenyataan dan harapan pelanggan atas layanan yang mereka terima atau peroleh. Kualitas pelayanan sangat erat kaitannya dengan kepuasan konsumen, kualitas yang diberikan oleh perusahaan menjadi sarana penunjang untuk mencapai kepuasan, hal ini dikarenakan jika adanya pelayanan yang baik dari perusahaan maka pelanggan akan merasakan adanya perlakuan lebih yang diberikan perusahaan terhadap konsumen. Dengan kata lain konsumen akan merasa puas dengan apa yang telah diberikan oleh perusahaan.

\section{Efek Harga terhadap Kesetiaan Pelanggan}

Penetapan harga yang tepat terhadap suatu produk atau jasa merupakan suatu hal yang penting dilakukan perusahaan dalam membangun loyalitas atau kesetiaan pelanggan. Keputusan penentuan harga demikian penting dalam menemukan seberapa jauh sebuah layanan jasa dinilai oleh konsumen dan juga dalam proses membangun tingkat loyalitas konsumen Lupiyoadi (2008) dalam Putra (2012). Penentuan harga sangat penting mengingat produk yang ditawarkan oleh jasa layanan tersebut bersifat tidak berwujud.

\section{Efek Promosi terhadap Kesetiaan Pelanggan}

Loyalitas atau kesetiaan pelanggan perlu diperoleh karena pelanggan yang setia akan aktif berpromosi memberikan rekomendasi kepada keluarga dan sahabatnya untuk menjadikan produk sebagai pilihan utama dan tidak mudah dipindahkan. Para peneliti seakan sepakat 
bahwa kepuasan pelanggan merupakan faktor utama yang dapat menarik kesetiaan pelanggan. Promosi adalah suatu kegiatan untuk menyampaikan informasi atau berkomunikasi antara penjual dan pembeli potensial yang besifat menyebarkan informasi, mempengaruhi, membujuk, dan mengingatkan pasar sasaran untuk menciptakan permintaan atas produk barang atau jasa yang ditawarkan perusahaan. Penelitian Pi dan Huang (2011) menjelaskan bahwa promosi berpengaruh positif terhadap kesetiaan pelanggan.

\section{Efek Kualitas Pelayanan terhadap Kesetiaan Pelanggan}

Kualitas pelayanan merupakan tingkatan kondisi baik buruknya sajian yang diberikan dalam rangka memuaskan konsumen, dalam perusahaan jasa tentu bukanlah sesuatu yang mudah didefinisikan, karena hal tersebut sangat berhubungan erat dengan pandangan konsumen. Hal ini sesuai pernyataan Lupiyoadi dalam Putra (2012) bahwa salah satu yang mempengaruhi tingkat loyalitas konsumen adalah kualitas pelayanan. perusahaan perlu meningkatkan kualitas jasa untuk mengembangkan loyalitas pelanggannya, karena produk atau jasa yang berkualitas rendah akan menanggung risiko pelanggan tidak setia. Jika kualitas diperhatikan, maka loyalitas pelanggan akan lebih mudah diperoleh.

\section{Efek Kepuasan Konsumen terhadap Kesetiaan Pelanggan}

Setiap para pelaku usaha berharap bahwa pencapaian upayanya tidak berhenti pada satu titik dimana para pelanggannya mengalami kepuasan, tetapi selalu berharap bahwa pelanggannya akan menjadi loyal terhadap produk atau jasa yang dikonsumsinya. Karena menurut Olorunniwo, et. al, (2006), Kartajaya, dalam Astawa (2008) pelanggan yang terpuaskan cenderung untuk loyal atau setia terhadap penyedia barang atau jasa. Menurut Hasan (2009), pada tingkat dimana pelanggan berada pada tingkat kepuasan dan loyalitas yang tinggi. (Oloruniwo, 2006, et.al, Kartajaya dalam Astawa (2008) kepuasan ini akan mendorong konsumen atau pelanggan untuk melakukan pembelian atau mengonsumsi secara berulang berharap barang atau jasa yang menimbulkan kepuasan tersebut.

\section{Efek Harga terhadap Kesetiaan Pelanggan melalui Kepuasan Konsumen}

Harga, dilihat dari sudut pandang pelanggan, seringkali digunakan sebagai indikator nilai bilamana harga tersebut dihubungkan dengan manfaat yang dirasakan atas suatu barang atau jasa. Pada tingkat harga tertentu, jika manfaat yang dirasakan meningkat, maka nilainya 
akan meningkat pula. Apabila nilai yang dirasakan pelanggan semakin tinggi, maka akan menciptakan kepuasan pelanggan yang maksimal (Tjiptono, 2009). indikator harga dapat dilihat dari kesesuaian antara suatu pengorbanan dari pelanggan terhadap nilai yang diterimanya setelah melakukan pembelian, dan dari situlah pelanggan akan loyal dari produk atau jasa tersebut. harga yang positif merupakan hasil dari rasa puas akan suatu pembelian yang dilakukannya, sehingga terciptanya kesetian untuk membeli ulang.

\section{Efek Promosi terhadap Kesetiaan Pelanggan melalui Kepuasan Konsumen}

Menurut Cannon, dkk (2008), mendefinisikan promosi adalah mengkomunikasikan informasi antara penjual dan pembeli potensial atau orang lain untuk mempengaruhi sikap dan perilaku. Dimana promosi merupakan kegiatan manusia yang diarahkan kepada kepuasan konsumen pemenuhan kebutuhan dan keinginan konsumen melalui suatu proses pertukaran.

\section{Efek Kualitas Pelayanan terhadap Kesetiaan Pelanggan melalui Kepuasan Konsumen}

Kualitas pelayanan merupakan suatu bentuk penilaian konsumen terhadap tingkat layanan yang diterima (perceived service) dengan tingkat layanan yang diharapkan (expected service). Kualitas layanan mempunyai pengaruh terhadap kepuasan pelanggan (Cronin dan Taylor, dalam Prabowo 2006).

\section{Populasi dan Sampel}

Populasi yang digunakan dalam penelitian ini adalah seluruh pelanggan yang membeli dan mengkonsumsi makanan siap saji dalam periode satu bulan (Agustus 2016) dari King Burger di kota Batam sebanyak 1350.

Dalam penelitian ini sampel yang diambil dari populasi dilakukan dengan purposive sampling didasarkan pada beberapa kriteria yaitu:

1. pelanggan yang setia yang mengembalikan atau menukarkan 5 (lima) struk atau bill sebagai kupon untuk mendapatkan 1 burger gratis

Berdasarkan kriteria sampel tersebut, dari populasi pada King Burger Kota Batam, diperoleh sebanyak 93 sampel konsumen yang memenuhi syarat.

\section{Teknik Analisis Data}

Terdapat beberapa teknik untuk menganalisis data, yaitu: 
1. Analisis deskriptif merupakan statistik yang digunakan untuk menganalisa data dengan cara mendeskripsikan atau menggambarkan data yang telah terkumpul sebagaimana adanya tanpa bermaksud membuat kesimpulan yang berlaku untuk umum atau generalisasi.

2. Pengujian asumsi klasik dengan bantuan Software SPSS versi 22.00 Untuk menghasilkan suatu model yang baik, analisis regresi memerlukan pengujian asumsi klasik sebelum melakukan pengujian hipotesis. Pengujian asumsi klasik tersebut meliputi uji normalitas, uji linearitas, uji hipotesis.

\section{Pembahasan}

Koefisien jalur pertama menunjukkan bahwa secara langsung variabel Harga, Promosi dan Kualitas Pelayanan memiliki efek signifikan terhadap Kepuasan Konsumen. Hal ini dapat diketahui dengan melihat nilai sig. lebih kecil dari 0,05 bahkan semua variabel mendekati nol. Nilai sig. yang semakin mendekati nol atau semakin mengecil dari nilai 0,05 maka dapat disimpulkan semakin signifikan.

Koefisien jalur kedua menunjukkan bahwa secara langsung semua variabel eksogen baik Harga, Promosi dan Kualitas Pelayanan yang memiliki efek signifikan terhadap Kesetiaan Pelanggan, tetapi secara tidak langsung variabel Harga, dan Promosi tidak memiliki efek signifikan terhadap Kesetiaan Pelanggan melalui Kepuasan Konsumen. Dengan demikian dapat dikatakan bahwa melalui Kepuasan Konsumen apabila semua variabel eksogen ditingkatkan maka tidak akan diikuti peningkatan Kesetiaan Pelanggan kecuali hanya Kualitas Pelayanan yang dapat memiliki efek signifikan pada Kesetiaan Pelanggan.

\section{KESIMPULAN DAN SARAN}

\section{Kesimpulan}

Berdasarkan hasil penelitian dan pembahasan mengenai efek harga, promosi dan kualitas pelayanan terhadap kesetiaan pelanggan melalui kepuasan konsumen peneliti dapat mengambil kesimpulan sebagai berikut :

1. Harga memiliki efek signifikan terhadap Kepuasan Konsumen.

2. Promosi memiliki efek signifikan terhadap Kepuasan Konsumen.

3. Kualitas Pelayanan memiliki efek signifikan terhadap Kepuasan Konsumen. 
4. Kepuasan Konsumen memiliki efek signifikan terhadap Kesetiaan Pelanggan.

5. Harga memiliki efek signifikan terhadap Kesetiaan Pelanggan.

6. Promosi memiliki efek signifikan terhadap Kesetiaan Pelanggan.

7. Kualitas Pelayanan memiliki efek signifikan terhadap Kesetiaan Pelanggan.

8. Harga secara tidak langsung tidak memiliki efek signifikan terhadap Kesetiaan Pelanggan melalui Kepuasan Konsumen.

9. Promosi secara tidak langsung tidak memiliki efek signifikan terhadap Kesetiaan Pelanggan melalui Kepuasan Konsumen.

10. Kualitas Pelayanan secara tidak langsung memiliki efek signifikan terhadap Kesetiaan Pelanggan melalui Kepuasan Konsumen.

\section{Saran}

Saran yang penulis berikan setelah melakukan penelitian adalah sebagai berikut :

1. Melakukan evaluasi mengenai kontribusi tingkat Harga, melalui kepuasan konsumen sebagai variabel intervening terhadap kesetiaan pelanggan King Burger Kota Batam.

2. Berdasarkan penelitian mengenai tingkat Promosi di King Burger Kota Batam sudah tergolong baik, tetapi pihak perusahaan tetap harus meningkatkan ide dan kreatifitasnya dalam memberikan berbagai trik promosi yang menarik untuk menjadi daya tarik konsumen sehingga tercapainya Kesetiaan Pelanggan.

\section{REFERENSI}

Dutka, A, 1994, AMA Handbook for Customer Satisfaction : A Complete Guidance to Research, Planning and Implementation, NTC Business Books, Lincolnwood, Illionis.

Ghozali, I., 2007, Aplikasi Analisis Multivariate dengan Program SPSS, Universitas Diponegoro Semarang

Kotler, P., 1995, Marketing Management: Analysis, Planning, Implementation, and Control, Fifth Edition, Prentice Hall International. Inc:Uper Saddle River, New Jersey..

Kuncoro, M., 2003, Metode Riset untuk Bisnis dan Ekonomi, Erlangga: Jakarta.

Sugiyono, 2005, Statistika untuk Penelitian, Alfabeta: Bandung.

Yamit, Zulian, 2004, Manajemen Kualitas Produk dan Jasa, Ekonisia: Yogyakarta. 